\title{
Research Approaches for Determining Cold Requirements for Forcing and Flowering of Geophytes
}

\author{
John M. Dole ${ }^{1}$ \\ Department of Horticultural Science, Campus Box 7609, North Carolina State University, Raleigh, \\ NC 27695-7609
}

Many of the numerous geophytic plant species are commercially important floriculture crops, including Gladiolus L., Hyacinthus L., Iris L., Lilium L., Narcissus L., and Tulipa L. Lilium and Tulipa are two of the world's major floriculture crops with hundreds of cultivars being grown as potted flower plants, fresh cut flowers, and garden ornamentals. Geophytes are especially suitable for commercial floriculture production because the storage organs can be harvested, stored, and forced into flowering (programmed). Production time required for forcing is often short because the storage organ provides stored photosynthates for rapid growth. Unfortunately, only a few genera have been extensively studied, including Gladiolus, Hyacinthus, Iris, Lilium, Narcissus, and Tulipa. Hundreds of other species may also have high commercial potential but remain unstudied. One key factor in the cultivation and possible commercialization of new geophytes is that many species have cold requirements that must be characterized (Hartsema, 1961). Procedures for breaking dormancy are often complex and cannot be transferred from one species to the next. However, a number of basic patterns have emerged (Table 1).

Received for publication 4 Apr. 2002. Accepted for publication 4 Sept. 2002. Approved for publication by the Director, North Carolina Agricultural Experiment Station.

${ }^{1}$ E-mail: john_dole@ncsu.edu.

\section{Terminology}

Geophytes are plants in which the perennial buds are situated below ground on a storage organ such as a rhizome, tuber, corm, or bulb. Rhizomes, such as with Alstroemeria L. are modified, elongated, underground stems which grow horizontally with well-defined nodes. Tubers have nodes marked only by small buds and are separable into three types: root and stem tubers and enlarged hypoctyls. Root tubers, e.g., Dahlia Cav., have vegetative buds only at the apex of the storage organ and the primary storage tissue is the root. Stem tubers, such as with Solanum tuberosum L., have buds distributed over the entire surface and the primary storage tissue is the stem. Enlarged hypocotyls, such as with Cyclamen L., are similar to stem tubers but the primary storage tissue has been derived from the hypocotyl. Corms, e.g., Gladiolus, are modified stems with well-defined nodes and can be differentiated from rhizomes in that they are typically round, have a vertical axis of growth and form on top of the previously planted and senescing corm. In bulbs the primary storage organ is the swollen leaf bases and/or scales (modified leaves), which are positioned atop a compressed short stem (basal plate). Hippeastrum Herb. is an example of a bulb composed of compressed leaf bases and Tulipa and Lilium exemplify bulbs with scales. In addition, bulbs can be either tunicate, enclosed in dry leaf bases, e.g., Tulipa and Hyacinthus, or nontunicate, without a covering, e.g., Fritillaria L. and Lilium. Other plant materials are occasionally lumped into the term geophyte, such as woody crowns and pseudobulbs. Woody crowns, in particular, can be difficult to differentiate from geophytes and are often cold stored and forced. However, geophytes will be defined in the strictest sense for this discussion.

\section{Role of storage organs}

Storage organs permit plants to survive periods of unfavorable weather conditions, such as high or low temperatures, drought, or improper light levels. Consequently, the success of a geophytic species depends on growing rapidly when environmental conditions are favorable. The growth period is often brief and plants become dormant when the conditions are not favorable. Geophytic species respond to many environmental signals that determine when to enter or exit dormancy, including temperature, moisture, and photoperiod. For example, with Dahlia hybrids $(D$. coccinea Cav. $\times$ D pinnata Cav.) tuberous root formation is induced by photoperiods of 11-12 h or less. The dormant tuberous roots do not immediately resume growth unless they have been exposed to 0 to $10{ }^{\circ} \mathrm{C}$ for 6 weeks (Konishi and Inaba, 1967; Moser and Hess, 1968). Geophytes are found in a range of climates from tropical to arctic and, therefore, differ greatly in response to temperature. Species such as Tulipa require exposure to temperatures averaging $5^{\circ} \mathrm{C}$ for 
at least 10 to 12 weeks to break dormancy (Le Nard and De Hertogh, 1993a). In contrast, Leucocoryne coquimbensis F. Phil. requires $20{ }^{\circ} \mathrm{C}$ for at least 16 weeks (Ohkawa et al., 1998). Some species, e.g., Iris $\times$ hollandica hort., require a combination of temperatures, e.g., $30^{\circ} \mathrm{C}$ for at least 15 weeks followed by 6 to 13 weeks of 9 to $15^{\circ} \mathrm{C}$ for dormancy release (Hartsema, 1961).

\section{Effects of low treatment on plant development}

The role of low temperatures in the life cycle of the geophyte varies and plants can be categorized into three groups: 1) Cold is required for growth and development (endodormancy) and the plant cannot complete its life cycle without a cold period. For example, Tulipa requires a cold treatment for shoot elongation and flowering (Le Nard and De Hertogh, 1993a). 2) Cold is required for continued growth and development if dormancy has been induced (endodormancy), however, the plant can flower and complete its life cycle without a dormancy period. For example, exposure to daylengths of $12 \mathrm{~h}$ or less induces hypocotyl enlargement and dormancy in tuberous begonias (Lewis, 1951) and several weeks of 1 to $5{ }^{\circ} \mathrm{C}$ are required to break dormancy (Haegeman, 1993). However, when tuberous begonias are grown under 14-h daylengths without exposure to a cold period, the plants do not develop dormancy and flower (Lewis, 1951). 3) Cold is not required but prevents growth and development and reduces desiccation (ecodormancy). For example, Hippeastrum bulbs do not require a cold treatment, but bulbs are stored at $5-9{ }^{\circ} \mathrm{C}$ to delay flower and leaf emergence and allow storage and shipping (Boyle and Stimart, 1987; Rees, 1985).

Low temperatures also effect specific aspects of growth, and the optimum temperature varies with stage of growth. For example, flower scape development in Allium aflatunense $\mathrm{B}$. Fedtsch. bulbs is greatest at $11^{\circ} \mathrm{C}$, but the greatest root dry weight occurs at 8 to $11{ }^{\circ} \mathrm{C}$ (Zimmer and Renken, 1984; Zimmer et al., 1985). Sixteen weeks of $5^{\circ} \mathrm{C}$ is optimum for leaf growth and 20 weeks of $5^{\circ} \mathrm{C}$ is optimum for flower scape elongation. Tulipa bulbs initiate foliage, flowers, and roots at 18 ${ }^{\circ} \mathrm{C}$ (Le Nard and De Hertogh, 1993a; Shoub and De Hertogh, 1975). However, flower scape elongation commences after at least 10 to 12 weeks at $0-9{ }^{\circ} \mathrm{C}$.

\section{Commencing cold treatment}

Juvenility. A primary consideration for floriculturists is to determine when to begin the cold treatment. Geophytes must be physiologically capable of perceiving the cold treatment. Juvenility is the early stage of plant growth in which the plant is incapable of flowering despite being exposed to reproductive conditions. While the minimum number of leaves (nodes) is commonly used to indicate the end of juvenility for many nongeophytic plant species such as Antirrhinum majus L. at 18-22 leaves (Cockshull, 1985) and Campanula L.
'Champion' at 8-9 leaves (Cavins and Dole, 2001), the juvenility period for geophytes is typically determined by minimum storage organ circumference (Fortanier, 1973). Juvenility periods range from $\approx 1$ year and 3 to $4 \mathrm{~cm}$ in circumference for Triteleia Lindl. corms to 4 to 7 years and 6 to $10 \mathrm{~cm}$ in circumference for Tulipa bulbs.

Storage organ size. Organ size is important in that a plant may not be able to produce quality flowers, if the storage organ is too small prior to cold treatment. For example, large Liatris corms produce more flowering stems than small corms (Waithaka and Wanjao, 1983). Plants must attain proper photosynthate storage capacity before being subjected to reproductive conditions. In addition, early exposure to reproductive conditions before storage organs reach sufficient size (end of juvenility) may decrease uniformity of flowering (Cameron et al., 1996).

Pretreatments. For some species, cold treatments are required after specific environmental stimuli, e.g., high temperatures or drought stress, have been completed (Boyle and Stimart, 1987; Hartsema, 1961; Lewis, 1951). Such pretreatments are imposed to either delay development and allow extended storage of the organs or to accelerate development and allow forcing as quickly as possible after bulb harvest. For example, Iris $\times$ hollandica bulbs are exposed to warm $\left(30^{\circ} \mathrm{C}\right)$ temperatures to retard further development prior to cool $\left(9-15^{\circ} \mathrm{C}\right)$ temperatures for dormancy release (Hartsema, 1961). Heat treatment for retardation allows the iris to be forced year-round for cut flower production.

Anatomical markers. Many studies have been based on time after harvest or anatomical markers, such as size of the apical meristem, and anatomical development of floral or vegetative organs (Le Nard and De Hertogh, 1993a). For example, Tulipa bulbs are considered to be physiologically responsive to a cold treatment when the apical meristem has reached "Stage G" - the stage at which all floral organs have been differentiated and are visible upon dissection of the bulb (Le Nard and De Hertogh, 1993a).

Biochemical markers. Several researchers have attempted to provide more accurate indications of when to commence the cold treatment by biochemical means, e.g., specific levels of various carbohydrates and endogenous plant growth regulators (Farooq and Koul, 1983; Gilbertson-Ferriss et al., 1981c; Rudnicki and Nowak, 1976). Theoretically, after specific and reliable markers have been discovered, the challenge would be to find reliable methods for rapidly and accurately testing sufficiently large numbers of bulbs to allow commercial use of the methodology.

\section{Cold treatment}

Duration. Another key consideration for floriculturists is to determine the length of the cold treatment. Research on cold treatment of geophytes can involve whole plants; the storage organs, either potted or unpotted, are subjected to cold temperatures for a range of durations
(De Hertogh and Gallitano, 1997; Jansen van Vuuren, 1997; Roh et al., 1995). The plants are subsequently forced in a greenhouse or planted in fields. These studies provided both practical information for growers and data on which to base further studies. The next step is to refine the cold treatment process and answer one or more of the following questions: 1) what is (are) the optimum temperature(s);2) what is the optimum duration; 3 ) should storage organs be unplanted (dry or moist) or planted and moist during the cold period; and 4) is light required during the cold treatment if shoots are present? Research can precisely defined the cold treatment, which may be expressed as degreehours - the number of hours below a specific temperature. For example, the optimum cold period for Lilium longiflorum Thunb. is 1000 $\mathrm{h}$ at temperatures of 2 to $7^{\circ} \mathrm{C}$ (Stuart, 1954). The bulbs must be moist to perceive the cold temperature and the highest quality plants and flowers are obtained when the bulbs are potted and allowed to form roots prior to the treatment. Light is not required but is beneficial if shoots emerge during the cold treatment.

Morphological markers. Morphological markers, such as root and/or shoot growth, are often used to determine when chilling is sufficient or when a specific cold treatment stage has been completed. For example, the temperature is usually dropped from 9 to $5^{\circ} \mathrm{C}$ when sufficient Tulipa root growth has occurred and then to $0-2{ }^{\circ} \mathrm{C}$ when sufficient shoot growth has occurred (De Hertogh, 1996; Le Nard and De Hertogh, 1993a). In this case, root growth and shoot growth are used as physiological markers indicating the completion of specific stages of growth during the cold treatment.

Biochemical markers. Studies are being conducted to provide accurate indications of the end of the cold treatment by biochemical means (Boonekamp et al., 1990). The levels of various carbohydrates and endogenous plant growth regulators have been studied in several species, including Freesia ecklon ex Klatt. (Gilbertson-Ferriss et al., 1981a, 1981b; Masuda and Asahira, 1978), Hyacinthus (Rudnicki and Nowack, 1976), Iris (De Munk and Schipper, 1993), Liatris (Keren-paz et al., 1989), Lilium (Lin et al., 1975; Miller and Langhans, 1990; Ohkawa, 1977; Takayama et al., 1993; Wang and Roberts, 1970), Narcissus (Aung et al., 1969; Edelbluth and Kaldewey, 1976; Hanks et al., 1986; van Staden, 1978), and Tulipa (Hanks and Rees, 1980; Hobson and Davies, 1977; Rebers et al., 1996; Rietveld et al., 2000; Terry et al., 1982). A decline in the levels of endogenous gibberellin-like substances in Lilium speciosum rubrum Mast. ex Bak. bulbs has been associated with dormancy breaking and shoot elongation (Ohkawa, 1977). When accurate markers have been established, the challenge will be to find methods for rapidly and accurately testing sufficiently large numbers of bulbs to allow commercial use of the methodology (Boonekamp et al., 1990).

\section{Other considerations for cold treatments}

Optimum vs. acceptable conditions. Other factors must be considered with regard to cold 
treatments. First, the distinction must be made between optimum and acceptable conditions. Optimum conditions are those which produce high quality plants in a short period of time; while acceptable conditions are those which either produce high-quality plants in a long period or rapidly produce a low-quality plant. For example, the optimum cold temperature and duration for L. longiflorum are $1000 \mathrm{~h}$ at 2 to $7{ }^{\circ} \mathrm{C}$ (Stuart, 1954). However, dormancy can be broken by temperatures from 1 to 18 ${ }^{\circ} \mathrm{C}$ and durations of cold from a minimum of 2 weeks up to several months (De Hertogh and Wilkins 1971a, 1971b; Lin and Wilkins, 1973). Suboptimal conditions may be used for short durations but are typically not used commercially because they will result in either excessively long production times or poor quality plants.

Cultivar responses. Large variations exist among the cultivars of most species. The Holland Bulb Forcer's Guide (De Hertogh, 1996) contains extensive tables illustrating the differences among cultivars with regard to the optimum cold durations for Crocus L., Hyacinthus, Iris, Narcissus, Tulipa, and many other species. Unfortunately, monetary and space constraints often limit cultivars tested to only one or a few at best. A complication is that interspecific hybrids often have diverse cold responses and many commercially important species are hybrids.

Reversal of cold treatment. The potential to reverse the cold treatment, also known as devernalization, is rarely studied. Warm temperatures may have no effect on the cold response or may reduce or cancel the effects of prior cold treatments (Miller and Kiplinger, 1966). As with the determination of optimum cold requirements, the range and duration of temperatures that can reverse the cold response must be determined. For example, temperatures above $21{ }^{\circ} \mathrm{C}$ for an extended duration immediately after cold storage of $L$. longiflorum plants erased the cold treatment and delayed flowering (Miller and Kiplinger, 1966).

\section{Replacing cold treatments}

One final area of research and commercial interest is to find treatments that partially or completely replace cold treatments. Cold treatments typically require one or more controlled temperature rooms, which have limited space and are expensive to construct and maintain. In addition, cold treatments are often required for extended periods. Partially or completely replacing the cold treatment can reduce production time and expense. Research into cold replacements can also provide data on the physiology of cold responses. Generally cold replacement treatments focus on plant growth regulators, e.g., gibberellic acid (GA) and ethylene, and photoperiod. For example, GA is effective in replacing the cold treatment of mature Gladiolus corms (Bhattacharjee, 1984; Dua et al., 1984; Ginzburg, 1974; Tonecki, 1980). More common, however, are the situations where plant growth regulators only partially substitute for cold treatments. GA application to Liatris spicata (L.) Willd. did not break dormancy or induce flowering; however, $100 \%$ flowering occurred when GA was applied to corms that had been exposed to $2{ }^{\circ} \mathrm{C}$ for 5 weeks (Zieslin and Geller, 1983). Only 66\% of the corms receiving only $2{ }^{\circ} \mathrm{C}$ for 5 weeks flowered. Ethylene has been used to replace or shorten the heat pretreatment required for Iris bulbs (De Munk and Schipper, 1993) and Freesia corms (Uyemura and Imanishi, 1983, 1984) prior to cold treatment. Interestingly, wounding of tulip bulbs partially replaced the cold treatment and decreased time to flower, possibly through stimulation of ethylene production (Kawa et al.,1993).

As with plant growth regulators, photoperiod can completely or partially substitute for the cold treatment. For example, 4 to 5 weeks of the optimum 6 weeks of cold treatment can be replaced in L. longiflorum by exposure to long photoperiods, but long days alone do not induce flowering since a minimum of 1 to 2 weeks of cold must be used (Dole and Wilkins, 1994; Weiler and Langhans, 1968, 1972).

While the use of replacement treatments may reduce or eliminate problems associated with cold treatments, problems can occur. Chemical treatments rarely provide as uniform a response as cold treatment. Chemicals may not be absorbed by or translocated within the geophyte uniformly. In addition, a variety of legal issues may exist regarding chemical use and the possibility of phytotoxicity.

\section{Developing a research plan on the use of temperature treatments to break dormancy}

The first step in developing a research program on chilling geophytes is to determine the origin of the species, e.g., temperate or tropical. This provides important guidelines regarding temperature treatments required to break dormancy (Ferreira and Hancke, 1985; Fritsch, 1997; Gutterman, 1997). Many geophytes from temperate climates require a low temperature; Fritillaria imperalis L., for example, requires 4 months of $2{ }^{\circ} \mathrm{C}$ for forcing and flowering (Le Nard and De Hertogh, 1993b). Unfortunately, the specific climatic conditions under which a species grows are not documented for many species. Records, such as temperature, photoperiod, rainfall, and soil type, are required. In addition, a species may exhibit physiological responses in cultivation that were not expected based on the origin of the species. For example, L. longiforum is native to the tropical islands of southern Japan where sugar cane (Saccharum officinarum L.) grows nearby but yet has a 2 to $7^{\circ} \mathrm{C}$ optimum temperature for cold treatment. The tropical nature of L. longiflorum is evident by the fact that night temperatures as high as $18{ }^{\circ} \mathrm{C}$ can provide the necessary cold requirement for flowering (Weiler and Langhans, 1968).

Many factors will need to be examined to develop commercially feasible cold storage protocols for a new geophytic species. For initial studies $5{ }^{\circ} \mathrm{C}$ can be used for temperate geophytes or 18 to $23{ }^{\circ} \mathrm{C}$ for tropical geophytes over a range of time periods, such as $0,4,8,12,16$, or 20 weeks. Han et al. (1991) showed that increasing duration of $5^{\circ} \mathrm{C}$ storage of Triteleia laxa Benth. corms for 0,5 , or 12 weeks reduced time to anthesis during forcing to 144,114 , or $77 \mathrm{~d}$, respectively. For the tropical species Leucocoryne coquimbensis, Ohkawa et al. (1998) found that $20{ }^{\circ} \mathrm{C}$ was the optimum dormancy breaking temperature when compared to $0,5,10,15,25$, or $30^{\circ} \mathrm{C}$ and bulbs could be stored at $20^{\circ} \mathrm{C}$ for up to 11 months (Ohkawa et al., 1998).

The effectiveness of temperatures other than $5{ }^{\circ} \mathrm{C}$ must be determined. van Leeuwen and Dop (1990) concluded that $2{ }^{\circ} \mathrm{C}$ was the optimum cold storage temperature for Oxalis adenophylla Gillies. because 5 and $9{ }^{\circ} \mathrm{C}$ resulted in fewer flowers, less uniform flowering, and flower stems covered by the foliage. However, Jansen van Vuuren and Holtzman (1992) stored Ornithogalum thyrsoides Jacq. for 14 weeks at $5,10,15,20,25,30$, or $35^{\circ} \mathrm{C}$ and noted that bulbs stored at $5{ }^{\circ} \mathrm{C}$ reached anthesis in the fewest number of days. When the storage temperature increased, days to anthesis increased.

The effect of daily thermoperiodism should be determined. Scilla autumnalis L. and Urginea maritima (L.) Bak. did not flower when bulbs were held at constant 10 , 15 , or $20{ }^{\circ} \mathrm{C}$ but flowered when held at 20 ${ }^{\circ} \mathrm{C}$ day and $10^{\circ} \mathrm{C}$ night (Halevy, 1990; McCrohan, 1990).

The effect of photoperiod after cold treatment and forcing of the storage organ should be determined. Days to anthesis of Allium ampeloprasum L. bulbs (De Hertogh and Zimmer, 1989) and Triteleia laxa corms (Han et al., 1991) were reduced by growing plants under 16-h long days during forcing after cold treatment. Generally photoperiod is not a factor prior to the cold treatment. However, decreasing the daylength from 18 to $9 \mathrm{~h}$ decreased the days to anthesis for Colchicum tunicatum Feinbr. bulbs, as long as the temperature was above $29^{\circ} \mathrm{C}$ (Gutterman, 1989; Gutterman and Boekon, 1989). Significantly, the photoperiodic response occurred even though the dry corms were below the soil surface. Gutterman (1989) theorized that dry tubular cataphylls, which reach the soil surface, were able to transmit the light signal to the corms.

Drought stress may be required or beneficial prior to geophyte harvest and subsequent cold treatment and forcing. For example, when actively growing Hippeastrum 'Red Lion' bulbs were allowed to dry for $0,2,4$, or 8 weeks, 4 to 8 weeks of drought stress resulted in $100 \%$ flowering in 140 or $60 \mathrm{~d}$, respectively. In contrast bulbs drought stressed for 2 weeks flowered in $160 \mathrm{~d}$ (Boyle and Stimart, 1987). Only $83 \%$ of the unstressed bulbs flowered and those bulbs required at least $160 \mathrm{~d}$ to reach anthesis.

A period of warm temperatures, i.e., 25 to $30{ }^{\circ} \mathrm{C}$, may be required or beneficial prior to geophyte chilling and forcing. Warm temperature treatments are usually effective on dry, unplanted storage organs. Freesia corms are typically stored at $30^{\circ} \mathrm{C}$ for a minimum of 15 to 16 weeks prior to receiving cold temperatures of 13 to $15{ }^{\circ} \mathrm{C}$ (Gilbertson-Ferris, 1985). A similar situation exists for iris bulbs (De Munk and Schipper, 1993). 
Table 1. Basic protocols for breaking dormancy of selected geophytic floriculture species (De Hertogh, 1996; De Hertogh and Le Nard, 1993; Dole and Wilkins, 1999).

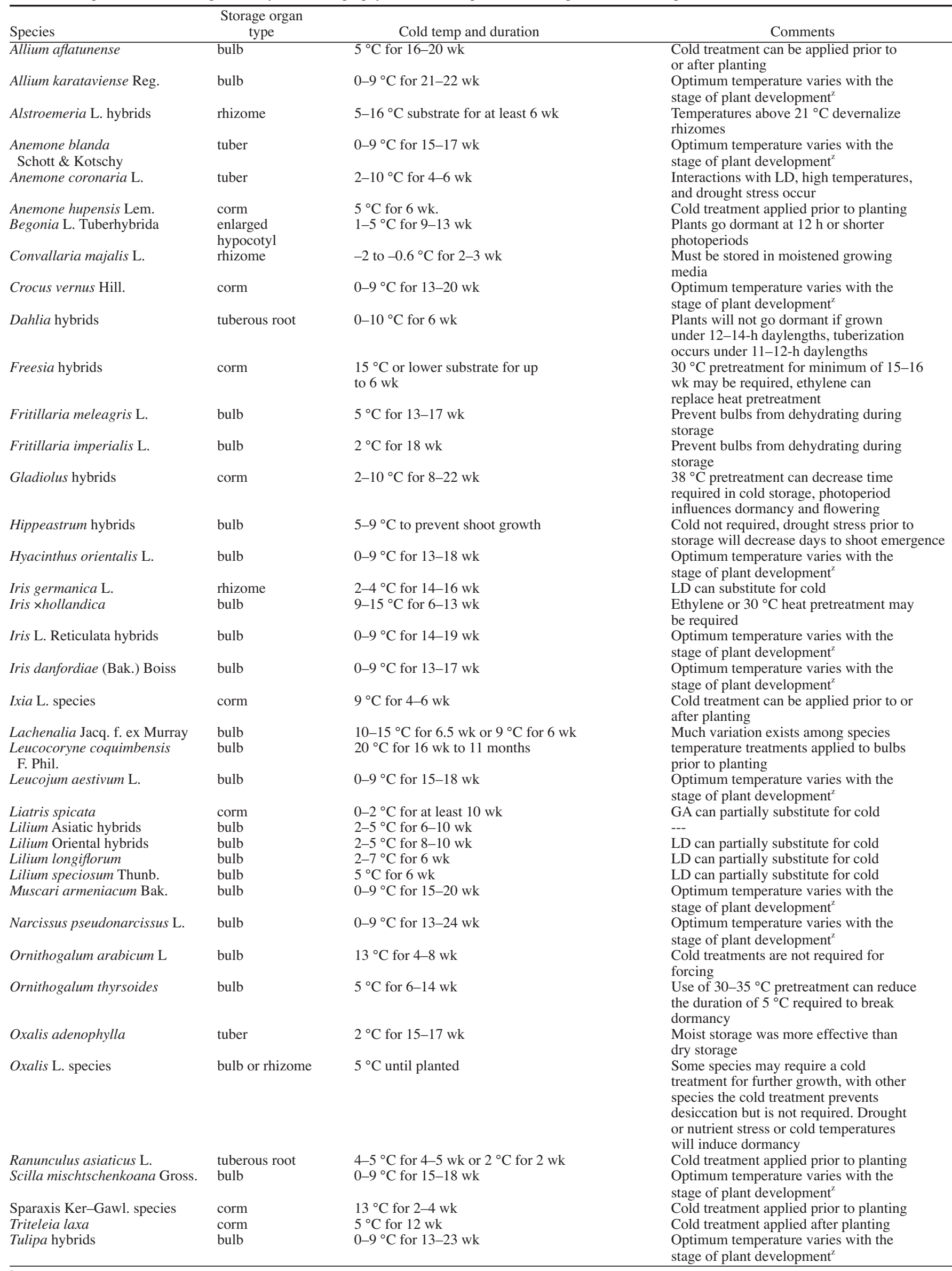

${ }^{2}$ After potting, the cold treatment typically starts at $9{ }^{\circ} \mathrm{C}$ until roots are visible at the bottom of the pot at which time the temperature is lowered to $5{ }^{\circ} \mathrm{C}$. When shoots are of proper length for the species, the temperature is dropped to and held at $0-2{ }^{\circ} \mathrm{C}$ until plants are moved to warm temperatures for forcing. 
Moist planted conditions may be required for perception of the cold treatment prior to forcing the storage organ. For example, L. longiflorum bulbs must be moist during the cold storage treatment. Laiche and Box (1970) showed that bulbs receiving 6 weeks of $7-10{ }^{\circ} \mathrm{C}$ cold flowered in $118 \mathrm{~d}$ when stored moist, but required $136 \mathrm{~d}$ when stored dry. In many cases dry bulbs can perceive the cold treatment but plant quality will be negatively affected if the storage organs are planted after the cold treatment has been applied and do not have a root system to support shoot elongation and flower development during forcing. When Tulipa bulbs were subject to various combinations of dry, unplanted and moist, planted conditions during 15 weeks of $5{ }^{\circ} \mathrm{C}$ cold storage, a minimum of 6 weeks moist, planted storage was required to prevent flower bud abortion during subsequent forcing at 17 ${ }^{\circ} \mathrm{C}$ in the greenhouse (Dole, 1994).

Once the effect of cold storage questions has been determined, the results may need to be refined to obtain commercial protocols. For example, do the processes of flower initiation, shoot elongation, and root development have the same optimum cold requirements or have different optimum requirements? In addition, the potential for devernalization should be investigated. The use of plant growth regulators or photoperiods to partially or completely replace the cold requirement should be determined. Plant growth regulators can be applied to dry unplanted geophytes or to plants being forced in the greenhouse. Photoperiod control can be accomplished during forcing.

\section{SUMMARY}

Geophytes are useful for commercial floriculture production because the storage organs can be harvested, stored, and forced into flower. Time required for forcing is often short because the storage organ provides sufficient stored photosynthates for rapid growth. Commercial development of new geophytic species may involve determining cold treatment requirements for breaking dormancy. Before cold treatments can be applied, the storage organ must be "physiologically mature" and of sufficient size to produce quality plants. High temperature or drought stress pretreatments may be required. The optimum duration and temperature of the cold treatment must be determined. Moisture may also be required for perception of the cold treatment. Anatomical markers to indicate the proper time to initiate or terminate cold treatments are available for a limited number of species. Biochemical markers must be investigated and made commercially useful. Other considerations include determining optimum vs. acceptable conditions, cultivar differences, and conditions that may negate the cold treatment. Treatments to completely or partially replace the cold treatments are successful with some species and include photoperiod and plant growth regulators such as ethylene or gibberellic acid. For initial studies, $5^{\circ} \mathrm{C}$ can effectively break dormancy for many species from temperate climates.

\section{Literature Cited}

Aung, L.H.,A.A. De Hertogh, and G.L. Staby. 1969 Gibberellin-like substances in bulb species. Can. J. Bot. 47:1817-1819.

Bhattacharjee, S.K. 1984. The effect of growth regulating chemicals on gladiolus. Gartenbauwissenschaft 49:103-106.

Boonekamp, P.M., J.C.M. Beijersbergen, and J.M. Franssen. 1990. The development of flowering assays for cold-treated tulip bulbs. Acta Hort. 266:177-181.

Boyle, T.H. and D.P. Stimart. 1987. Influence of irrigation interruptions on flowering of Hippeastrum $\times$ hybridum 'Red Lion'. HortScience 22:1290-1292.

Cameron, A., M. Yuan, R. Heins, and W. Carlson. 1996. Juvenility: Your perennial crop's age affects flowering. GrowerTalks 60(8):30-32, 34 .

Cavins, T.J. and J.M. Dole. 2001. Photoperiod, juvenility, and high-intensity lighting affect flowering and cut stem qualities of Campanula and Lupinus. HortScience 36:1192-1196.

Cockshull, K.E. 1985. Antirrhinum majus, p. 476481. In: A.H. Halevy (ed.). Handbook of flowering, vol. III. CRC Press, Boca Raton, Fla.

De Hertogh, A.A. 1996. Holland bulb forcers' guide, 5 th ed. Intl. Flower Bulb Centre, Hillegom, The Netherlands.

De Hertogh, A.A. and L. Gallitano. 1997. Basic forcing requirements for Israeli-grown Ornithogalum dubium. Acta Hort. 430:227-232.

De Hertogh, A. and M. Le Nard (eds.). 1993. The physiology of flower bulbs. Elsevier Science Publishers, Amsterdam.

De Hertogh, A.A. and H.F. Wilkins. 1971a. The forcing of northwest-grown 'Ace' and 'Nellie White' lilies, Part 1. Florists' Rev. 149(3857):29-31.

De Hertogh, A.A. and H.F. Wilkins. 1971b. The forcing of northwest-grown 'Ace' and 'Nellie White' lilies, Part 2. Florists' Rev. 149(3858): 57, 104-111.

De Hertogh, A.A. and K. Zimmer. 1989. Allium-Ornamental species, p. 22-33. In: A.H. Halevy (ed.). Handbook of flowering, vol. VI. CRC Press, Boca Raton, Fla.

De Munk, W.J. and J. Schipper. 1993. Iris-Bulbous and rhizomatous, p. 349-379. In: A. De Hertogh and M. Le Nard (eds.). The physiology of flower bulbs. Elsevier Science Publishers, Amsterdam.

Dole, J.M. 1994. One cooler, single temperature cooling of potted tulips. HortScience 29:487. (Abstr.)

Dole, J.M. and H.F. Wilkins. 1994. Interaction of bulb vernalization and shoot photoperiod on 'Nellie White' Easter lily. HortScience 29:143-145.

Dole, J.M. and H.F. Wilkins. 1999. Floriculture principles and species. Prentice-Hall, Upper Saddle River, N.J.

Dua, I.S., O.P. Sehgal, and K.S. Clark. 1984. Gibberellic acid induced earliness and increased production in gladiolus. Gartenbauwissenschaft 49:91-94.

Edelbluth, E. and H. Kaldewey. 1976. Auxin in scapes, flower buds, flowers, and fruits of daffodil (Narcissus pseudonarcissus L.). Planta 131:285-291.

Farooq, S. and K.K. Koul. 1983. Changes in gibberellin-like activity in corms of saffron plant (C. sativus) during dormancy and sprouting. Biochem. Physiol. Pflanzen 178:685-689.

Ferreira, D.I. and F.L. Hancke. 1985. Indigenous flower bulbs of South Africa-A source of new genera and species for ornamental bulb cultivation. Acta Hort. 177:405-410.

Fortanier, E.J. 1973. Reviewing the length of the generation period and its shortening, particularly in tulips. Scientia Hort. 1:107-116.
Fritsch, R.M. 1997. Decorative Allium L. species of central Asia. Acta Hort. 430:809-814.

Gilbertson-Ferris, T.L. 1985. Freesia $\times$ hybrida, p. 34-37. In: A.H. Halevy (ed.). Handbook of flowering, vol. III. CRC Press, Boca Raton, Fla.

Gilbertson-Ferriss, T.L., M.L. Brenner, and H.F. Wilkins. 1981a. Effects of storage temperatures on endogenous growth substances and shoot emergence in Freesia hybrida corms. J. Amer. Soc. Hort. Sci. 106:455-460.

Gilbertson-Ferriss, T.L., M.L. Brenner, and H.F. Wilkins. 1981b. Localization of endogenous growth substances in Freesia hybrida 'Moya' corms before and after a heat treatment. J. Amer. Soc. Hort. Sci. 106:460-463.

Gilbertson-Ferriss, T., M.L. Brenner, and H.F. Wilkins. 1981c. Corm and shoot development of Freesia hybrida 'Super Emerald Mixture' as related to endogenous abscisic acid and indolacetic acid levels in the developing corm. J. Amer. Soc. Hort. Sci. 106:463-466.

Ginzburg, C. 1974. The effect of gibberellin $\mathrm{A}_{3}$ and (2-chloroethyl)-trimethylammonium chloride on assimilate distribution in gladiolus in relation to corm growth. J. Expt. Bot. 25:995-1003.

Gutterman, Y. 1997. Geophytes of the Negev as a genetic source for ornamental garden plants, cut flowers and pot plants. Acta Hort. 430: 783-794.

Gutterman, Y. 1989. Colchicum tunicatum, p. 234 242. In: A.H. Halevy (ed.). Handbook of flowering, vol. VI. CRC Press, Boca Raton, Fla.

Gutterman, Y. and B. Boeken. 1989. Flowering affected by daylength and temperature in the leafless flowering desert geophyte Colchicum tunicatum, its annual life cycle and vegetative propagation. Bot. Gaz. 149:382-390.

Haegeman, J. 1993. Begonia-Tuberous hybrids, p. 227-238. In: A. De Hertogh and M. Le Nard (eds.). The physiology of flower bulbs. Elsevier Science Publishers, Amsterdam.

Halevy, A.H. 1990. Recent advances in control of flowering and growth habit of geophytes. Acta Hort. 266:35-42.

Han, S.S.,A.H. Halevy, R.M. Saches, and M.S. Reid. 1991. Flowering and corm yield of brodiaea in response to temperature, photoperiod, corm size, and planting depth. J. Amer. Soc. Hort. Sci. 116:19-22.

Hanks, F.E. and A.R. Rees. 1980. Growth substances of tulip: The activity of gibberellin-like substances in field-grown tulips from planting until flowering. Zeitschrift für Pflanzenphysiologie 98:213-223.

Hanks, F.E., G. Shaik, and S.K. Jones. 1986. Bulbil production in Narcissus: The effect of temperature and duration of storage on bulb unit development and subsequent propagation by twin-scaling. Ann. Appl. Bot. 109:417-425.

Hartsema, A.H. 1961. Influence of temperatures on flower formation and flowering of bulbous and tuberous plants, p. 123-167. In: W. Ruhland (ed.). Handbuch der Pflanzenphysiologie, vol. 16. Springer-Verlag, Berlin.

Hobsen, G.E. and J.N. Davies. 1977. Mitochondrial activity and carbohydrate levels in tulip bulbs in relation to cold treatment. J. Expt. Bot. 28: 559-568.

Jansen van Vuuren, P.J. 1997. Predicting the flowering date of Ornithogalum thyrsoides (Jacq.). Acta Hort. 430:167-174.

Jansen van Vuuren, P.J. and L.C. Holtzman. 1992. The influence of temperature on phenological dating of Ornithogalum thyrsoides Jacq. as a commercial cut flower. Acta Hort. 325:119-129.

Kawa, L., M. Le Nard, and A.A. DeHertogh. 1993. The effects of scale wounding of tulip bulbs on ethylene evolution, plant growth and flowering. Scientia Hort. 53:347-359. 
Keren-Paz, V.,A. Borochov, and S. Mayak. 1989. The involvement of ethylene in liatris corm dormancy. Plant Growth Regulat. 8:11-20.

Konishi, K. and K. Inaba. 1967. Studies on flowering control of Dahlia. VII. On dormancy of crowntuber. J. Jpn. Soc. Hort. Sci. 36:131-140.

Laiche, A.J., Jr., and C.O. Box. 1970. Response of Easter lily to bulb treatments of precooling, packing media, moisture, and gibberellin. HortScience 5:396-397.

Le Nard, M. and A.A. De Hertogh. 1993a. Tulipa, p. 617-682. In: A. De Hertogh and M. Le Nard (eds.). The physiology of flower bulbs. Elsevier Science Publishers, Amsterdam.

Le Nard, M. and A.A. De Hertogh. 1993b. General chapter of spring flowering bulbs, p. 705-739. In: A. De Hertogh and M. Le Nard (eds.). The physiology of flower bulbs. Elsevier Science Publishers, Amsterdam.

Lewis, C. 1951. Some effects of daylength on tuberization, flowering, and vegetative growth of tuberous-rooted begonias. Proc. Amer. Soc. Hort. Sci. 57:376-378.

Lin, W.C. and H.F. Wilkins. 1973. The interaction of temperature on photoperiodic responses of Lilium longiflorum Thunb. cv. Nellie White. Florists' Rev. 153(3965):24-26.

Lin, W.C., H.F. Wilkins, and M.L. Brenner. 1975 Endogenous promoter and inhibitor levels in Lilium longiflorum. J. Amer. Soc. Hort. Sci. 100:9-16.

Masuda, M. and T. Asahira. 1978. Changes in endogenous cytokinin-like substances and growth inhibitors in freesia corms during high-temperature treatment for breaking dormancy. Scientia Hort. 8:371-382.

McCrohan, P. 1990. Urginea maritima 'Red Squill' as a cut flower. Herbertia 46:34-36.

Miller, R.O. and D.C. Kiplinger. 1966. Reversal of vernalization in northwest Easter lilies. Proc. Amer. Soc. Hort. Sci. 88:646-650.

Miller, W.B. and R.W. Langhans. 1990. Low temperature alters carbohydrate metabolism in Easter lily bulbs. HortScience 25:463-465.

Moser, B.C. and C.E. Hess. 1968. The physiology of tuberous root development in dahlia. Proc. Amer. Soc. Hort. Sci. 93:595-603.

Ohkawa, K. 1977. Studies on the physiology and control of flowering in Lilium speciosum rubrum. Spec. Bul. Kanagawa Hort. Expt. Sta. 1977:73.

Ohkawa, K.H.-H. Kim, E. Nitta, and Y. Fukazawa. 1998. Storage temperature and duration affect flower bud development, shoot emergence, and flowering of Leucocoryne coquimbensis F. Phil. J. Amer. Soc. Hort. Sci. 123:586-591.

Rebers, M.,E. Vermeer, E. Knegt, and L.H.W. van der Plas. 1996. Gibberellin levels are not a suitable indicator for properly cold-treated tulip bulbs. HortScience 31:837-838.

Rees, A.M. 1985. Hippeastrum, p. 294-296.In:A.H Halevy (ed.). Handbook of flowering, vol. I. CRC Press, Boca Raton, Fla.

Rietveld, P.L., C. Wilkinson, H.M. Franssen, P.A. Balk, L.H.W. van der Plas, P.J. Weisbeek, and A.D. de Boer. 2000. Low temperature sensing in tulip (Tulip gesneriana L.) is mediated through an increased response to auxin. J. Expt. Bot. 51:587-594

Roh, M.S., R.H. Lawson, C.-Y. Song, and E. Louw. 1995. Forcing Lachenalia as a potted plant Acta Hort. 397:147-153.

Rudnicki, R.M. and J. Nowak. 1976. Studies on the physiology of hyacinth bulbs (Hyacinthus orientalis L.). VI. Hormonal activities in hyacinth bulbs during flower formation and dormancy release. J. Expt. Bot. 27:303-313.

Shoub, J. and A.A. De Hertogh. 1975. Growth and development of the shoot, roots, and central bulblet of Tulipa gesneriana L. cv. Paul Richter during standard forcing. J. Amer. Soc. Hort. Sci. 100:32-37.

Stuart, N.W. 1954. Moisture content of packing medium, temperature and duration of storage as factors in forcing lily bulbs. Proc. Amer. Soc. Hort. Sci. 63:488-494.

Takayama, T., T. Toyomasu, H. Yamane, N. Murofushi, and H. Yajima. 1993. Lilium elegans Thunb. and their quantitative changes during cold treatment and the subsequent cultivation. J. Jpn. Soc. Hort. Sci. 62:189-196.

Terry, P.H., L.H. Aung, and A.A. De Hertogh. 1982. Identification of abscisic acid in Tulipa gesneriana L. by gas-liquid chromatography with electron capture and combined gas- liquid chromatography and mass spectrometry. Plant
Physiol. 70:1574-1576.

Tonecki, J. 1980. Effect of growth regulation on shoot apex differentiation and changes in sugar and free amino acids in gladiolus (Gladiolus xhortorum cv Acca Laurentia). Acta Hort. 109: 347-349.

Uyemura, S. and H. Imanishi. 1983. Effects of gaseous compounds in smoke on dormancy release in freesia corms. Scientia Hort. 20:91-99.

Uyemura, S. and H. Imanishi. 1984. Effects of duration of exposure to ethylene on dormancy release in freesia corms. Scientia Hort. 22:383-390.

van Leeuwen, P.J. and A.J. Dop. 1990. Effects of storage, cooling and greenhouse conditions on Anemone blanda, Fritillaria meleagris and Oxalis adenophylla for use as potplant. Acta Hort. 266:101-107.

van Staden, J. 1978. The levels of endogenous cytokinins in daffodil bulbs stored under different environmental conditions. Zeitschrift für Pflanzenphysiologie 86:323-330.

Waithaka K. and L.W. Wanjao, 1983. The influence of corm source, age and size on growth and flowering of Liatris spicata L. Acta Hort. 134:95-100.

Wang, S.Y. and A.N. Roberts. 1970. Physiology of dormancy in Lilium longiflorum 'Ace', Thunb. J. Amer. Soc. Hort. Sci. 95:554-558.

Weiler, T.C. and R.W. Langhans. 1968. Determination of vernalizing temperatures in the vernalization requirement of Lilium longiflorum (Thunb.) cv. Ace. Proc. Amer. Soc. Hort. Sci. 93:623-629.

Weiler, T.C. and R.W. Langhans. 1972. Growth and flowering responses of Lilium longiflorum (Thunb.) cv. Ace to different daylengths. Proc. Amer. Soc. Hort. Sci. 97:176-177.

Zieslin, N. and Z. Geller. 1983. Studies with Liatris spicata Willd. 1. Effect of temperature on sprouting, flowering and gibberellin content. Ann. Bot. 52:849-853.

Zimmer, K. and M. Renken. 1984. Untersuchungen an Allium aflatunense. Deutscher Gartenbau 38: 2004-2008.

Zimmer, K., M. Walingen, and M. Renken. 1985. Untersuchungen zur periodischen Entwicklung von Allium aflatunense. Deutscher Gartenbau 39:594-596. 